\title{
Sentinel lymph node biopsy in endometrial cancer: description of the technique and preliminary results
} Endometrium kanserinde sentinel lenf nodu biopsisi: tekniğin tanımı ve ilk sonuçlar

\author{
Oğuzhan Kuru, Samet Topuz, Serhat Şen, Cem İyibozkurt, Sinan Berkman \\ Department of Obstetrics and Gynecology, Istanbul Faculty of Medicine, Istanbul University, istanbul, Turkey
}

\section{Abstract}

Objective: To measure the feasibility of sentinel lymph node technique in endometrial cancer.

Material and Methods: The study was designed as a prospective non-randomized case-control trial. Between 2010-2011, in Istanbul University, Istanbul Medical Faculty, Gynecologic Oncology department, 26 patients who were preoperatively evaluated as endometrial cancer enrolled in the study. Patients' detailed informed consent and ethics committee approval were obtained. Sentinel lymph node (SLN) detection rate was determined as the primary outcome. Sensitivity, specificity, positive and negative predictive values and particularly false negative results were determined as secondary outcomes. As a technique of SLN, injection of methylene blue to the subserosal myometrium of the uterine fundus via $5 \mathrm{cc}$ syringe following peritoneal aspiration cytology procedure was obtained. Surgery was made after injection for an average of 5 minutes due to the physiological spread of the blue dye. Then, the standard protocol of hysterectomy was performed and the retroperitoneum was opened to perform lymphadenectomy. The presence of lymph node regions, and presence of a sentinel node was recorded on the trial record form. Positive staining nodes were sent separately for pathological examination. In the course of the study due to insufficient rate of staining, the technique has been changed to cervical and multiple uterine injections.

Results: As the primary outcome, an SLN positivity rate of $23 \%$ in 6 patients with a total of 8 lymph nodes were found. The remarkable finding was that in the first technique, the rate was $1 / 16(6 \%)$, while the second technique, $5 / 10(50 \%)$, respectively. The difference is statistically significant $(p=0.001)$. In endometrial cancer stage I and II, secondary outcomes for sensitivity, specificity, positive predictive value, negative predictive value were $23 \%, 0 \%, 100 \%, 43 \%$, respectively. Because there were no metastatic lymph nodes found, false negative rate was $0 \%$.

Conclusion: SLN approach is not valuable enough to eliminate the need for lymphadenectomy. On the other hand, it facilitates scanning micrometastases and ultrastaging, while its clinical value has not yet been established. However, according to the recent pilot studies, it provides a means for assessing micrometastases for the medium-risk group for local recurrence.

(J Turkish-German Gynecol Assoc 2011; 12: 204-8)

Key words: Sentinel lymph node, endometrium cancer, surgical staging

Received: 3 August, 2011
Accepted: 16 September, 2011
Özet

Amaç: Sentinel lenf nodu tekniğinin endometriyum kanserinde uygulanabilirliğini ölçmek.

Gereç ve Yöntemler: Prospektif non-randomize vaka kontrol çalışması olarak, 2010-2011 yllanı arasında İstanbul Üniversitesi İstanbul Tıp Fakültesi, Kadın Hastalıkları ve Doğum Anabilim Dalı, Jinekolojik Onkoloji servisinde yapılan preoperatif değerlendirmesi endometriyum kanseri saptanan 26 olgu çalışmaya alındı. Çalışma için hastalardan aydınlatılmış onam formları ile etik kurul onayı alındı. Birincil sonuç olarak sentinel lenf nodu (SLN) saptanma oranı, sekonder sonuç olarak da yalancı negatiflik başta olmak üzere duyarlılık, özgüllük, pozitif ve negatif prediktif değerlerin saptanması belirlendi. SLN tekniği olarak periton yıkantı sitolojisini takiben uterus fundusta subserozal myometriyuma 5 cc injektör ile metilen mavisi verildi. Boya verilmesini takiben ortalama 5 dakika cerrahiye ara verilerek boya maddenin yayılması beklendi. Broad ligaman ve tubalar klempe edilerek tümör hücrelerinin mobilizasyonunun engellenmesi amaçlandı. Ardından standart histerektomi protokolü uygulandı. Retroperitoneum açlarak lenfadenektomi yapıldı. Çalışma formuna, çıkarılan lenf nodu bölgeleri ve varsa sentinel nodu varlığı kaydedildi. Pozitif boyanma gösteren lenf nodlarının patolojik incelemeye ayrıca gönderilmesi öngörüldü. Çalışmanın seyrinde boyanma oranı yetersiz görüldüğü için servikal ve multipl uterus injeksiyonu tekniğine geçildi.

Bulgular: Primer sonuç olan SLN pozitifliği 6 hastada toplam 8 lenf nodu ile \%23 oranında bulunmuştur. Illk teknikte oran 1/16 (\%6) iken ikinci teknikte 5/10 (\%50) olarak bulunmuştur. Aradaki fark istatistiksel olarak anlamlıdır $(p=0.001)$. Sekonder sonuçlar olarak evre I ve II endometriyum kanserinde SLN tekniğinin duyarlılığı $\% 23$, özgüllüğü $\% 0$, pozitif prediktif değeri $\% 100$, negatif prediktif değeri $\% 43$ olarak bulunmuştur. Yalancı negatiflik değeri de pozitif lenf nodu bulunmadığından \%0'da kalmıştır.

Sonuç: SLN yaklaşımı lenfadenektomi ihtiyacını bertaraf edecek kadar değerli olmamakla birlikte rutin pratikte tüm lenf nodlarına uygulamanın mümkün görünmediği ve tedavi yönetiminde oturmuş bir yeri olmayan ancak pilot çalışmalarda elde edilen verilere göre nüks için orta risk grubu kabul edilen mikrometastaz incelemesine imkan vererek ultrastaging şansı yaratmaktadır.

(J Turkish-German Gynecol Assoc 2011; 12: 204-8)

Anahtar kelimeler: Sentinel lenf nodu, endometriyum kanseri, cerrahi evreleme

Geliş Tarihi: 03 Ağustos 2011

Kabul Tarihi: 16 Eylül 2011 


\section{Introduction}

Endometrial cancer is the most common gynecologic cancer in developed countries and its incidence has been increasing $(1,2)$. Although the data has poor reliability, according to Turkish Health Statistics 2006 reports; the incidence of endometrium cancer is 0.0029 , which is the second most common gyenocologic cancer. Surgical staging of endometrial cancer in the early stage covers peritoneal cytology, total hysterectomy, bilateral salphingoopherectomy (BSO) and lymph node sampling. Mean prognostic factors are based on histological grade, depth of myometrial invasion and lymph node status (3). Positive lymph node status is the major prognostic factor and restricts the duration of disease-free survival. Positive lymph nodes at stage 1 endometrial cancer reduces 5 year disease-free survival rate to $54 \%$, while it was $90 \%$ if the nodes were negative (4). The chance of lymph node invasion depends on tumor size, proximity to the lymphatic space, the degree of tumor differentiation, and infiltration (5). Lymph node metastases ranged from $0 \%$ to $34 \%$ in early-stage endometrial cancer, and it is crucial to determine an accurate staging (6-8). Retrospective studies have shown the benefits of therapeutic lymphadenectomy $(9,10)$.

Hypothetically, if the presence of intraoperative lymphatic involvement is determined, the extent of surgery should be established. Burke and his colleagues published the first study on the use of sentinel lymph node in endometrial cancer 12 years ago (11). In this study, we aimed to measure the success of the feasibility and effectiveness of sentinel lymph node technique in early-stage endometrial cancer in our clinic.

\section{Materials and Methods}

\section{Study design}

This is a pilot study which was designed as a prospective non-randomised case-control research. The primary outcome obtained was sentinel lymph node (SLN) detection rate, with false negativity, sensitivity, specificity, negative predictive value as secondary outcomes. Between 2010-2011, in Gynecologic Oncology, Obstetrics and Gynecology, department of the Istanbul University, Istanbul Medical Faculty, 26 patients who were preoperatively evaluated as endometrial cancer were enrolled in the study. Patients' detailed informed consent and ethics committee approval were obtained. The patients' demographic data, histological diagnosis, grade, intraoperative and postoperative complications of the surgery, body mass index (BMI), and presence of diabetes were recorded.

\section{Inclusion criteria}

The presence of the histological diagnosis of primary endometrial cancer, signing of informed consent form, having no evidence of distant metastases or extra-uterine disease in preopative imaging procedures, non-recurrent disease, having no medical disease which contraindicated general anesthesia or conditions that makes it difficult to perform lymphadenectomy such as morbid obesity and congenital anomalies were obtained as inclusion criteria.

\section{Surgical tehnique}

The patients were operated with a Phannenstiel or midline incision according to their BMI and gynecological examination. Minimum surgical protocol involved abdominal washing cytology, abdominal hysterectomy, BSO, omental biopsy and external-internal-common iliac and obturator lymphadenectomy. Under the guidance of clinical datas and if surgical tehnique was feasible; total omentectomy, presacral and/or paraaortic lymphadenectomy were also performed.

As a technique of SLN, injection of methylene blue to the subserosal myometrium of uterine fundus via a $5 \mathrm{cc}$ syringe following periton aspiration cytology procedure was performed. Surgery was carried out after injection for average of 5 minutes due to the physiological spread of the blue dye. The broad ligament and the uterine tubes were clamped to prevent mobilization of tumor cells. The standard protocol of hysterectomy was performed; the retroperitoneum was opened to perform lymphadenectomy. The presence of lymph node regions, and a sentinel node was recorded in the trial record form. Positive staining nodes were sent separately for pathological examination. During the course of the study, due to an inadequate rate of staining, the technique was switched to cervical and multiple uterine injections after 16 patients in the serial. The new technique was performed as bilateral paratubal, posterior and anterior isthmic uterine wall injections of $0.5 \mathrm{cc}$ isosulphane blue dye in each of the areas. The period of time increased to 10 minutes before clamping the ligaments.

\section{Histological evaluation}

Pathologists evaluated the sentinel node and other nodes macroscopically. They were divided into those with gross metastatic nodes and normal-looking ones and were cut perpendicular to the axis. Each half was cut parallel at intervals of up to $5 \mathrm{~mm}$ across, and hematoxylin-eosin (HE) staining was performed. After the parallel sections of $3 \mathrm{~mm}$ were obtained, sentinel nodes were cut at $150 \mu \mathrm{m}$ intervals and at least 4 primary sections for HE staining, followed by 4 secondary cross-section were taken for immunohistochemistry (IHC). For IHC staining, the anti-cytokeratin antibody (Cytokeratin AE1-AE3, Dako Corporation, Glostrup, Denmark) was used. The definition of micrometastasis in lymph node metastases between 0.2 and 2 $\mathrm{mm}$ in size were identified. The histological typing, grading and staging of the primary tumor were based on the FIGO system.

\section{Statistical analysis}

The results of 16 cases with myometrial subserosal methylene blue dye injection and 10 cases with both cervical and uterine isosulphane blue dye injection were compared by the MannWhitney test. Because of the absence of lymphatic metastasis, logistic regression analysis could not be performed to investigate the possibility of lymphatic metastasis.

\section{Results}

In demographic data; the mean age of the patients was $57.73 \pm 6.36$ (42-79), the mean gravida was $3.34(0-8)$, average parity was 2.07 (0-5) and except for 6 cases (23\%), all cases 
were at the postmenopausal stage. The average body mass index was $35.25 \pm 5.58$ (20.3 to 45.7). Histological types were endometrioid adenocarcinoma (24 cases, 92\%), serous papillary carcinoma (1 case, 4\%), and clear cell carcinoma (1 case, 4\%) (Table 1).

The second technique was applied in two cases of nonendometrioid type. In 5 cases (19.2\%), over $50 \%$ of the depth of myometrial invasion was detected. Para-aortic lymphadenectomy was applied in only two cases (7.6\%). On the other hand, lymph node metastases were not found in any of the patients (0\%). The average tumor volume was $20.15 \mathrm{cc}$. Lymphovascular invasion (LVAI) was found in $6(23 \%)$ cases. In fewer than expected only 5 cases, (19.2\%) had diabetes mellitus while 14 patients (53.7\%) had hypertension. It was found to be remarkable that only half of 4 cases which were shown to have greater than 50\% myometrial invasion, correlate with the final pathology report. The primary outcome of SLN positivity was detected with 6 patients (23\%) with a total of 8 lymph nodes. The detection rate of the first technique was $1 / 16(6 \%)$, while the second technique 5 /10 (50\%), which was found statistically significant $(\mathrm{p}=0.001)$.

None of the patients suffers from intraoperative or postoperative complications which prolongs the duration of hospital stay or requires re-hospitalization. As secondary outcomes, the sensitivity, specificity, positive predictive value, negative predictive value of SLN biopsy technique in stage I and II endometrial cancer was $23 \%, 0 \%, 100 \%$ and $43 \%$, respectively. The negative

Table 1. Demographic and clinical data of the patients

\begin{tabular}{|c|c|}
\hline \multicolumn{2}{|l|}{ Age range years } \\
\hline $40-50$ & $6(23 \%)$ \\
\hline $50-60$ & $9(35 \%)$ \\
\hline $60-70$ & $8(31 \%)$ \\
\hline $70-80$ & $3(11 \%)$ \\
\hline \multicolumn{2}{|l|}{$\mathrm{BMI} \mathrm{kg} / \mathrm{m}^{2}$} \\
\hline$<35$ & $11(42 \%)$ \\
\hline$>35$ & $15(58 \%)$ \\
\hline \multicolumn{2}{|l|}{ Parity } \\
\hline$\leq 3$ & $21(80 \%)$ \\
\hline$>3$ & $5(20 \%)$ \\
\hline \multicolumn{2}{|l|}{ Stage } \\
\hline I & $24(92 \%)$ \\
\hline II & $2(8 \%)$ \\
\hline \multicolumn{2}{|l|}{ Histologic type } \\
\hline Endometrioid & $24(92 \%)$ \\
\hline Serous & $1(4 \%)$ \\
\hline Clear cell & $1(4 \%)$ \\
\hline \multicolumn{2}{|l|}{ Grade } \\
\hline I & $20(77 \%)$ \\
\hline II & $6(23 \%)$ \\
\hline
\end{tabular}

predictive value was $0 \%$ because of the absence of positive lymph nodes. The most common region of 8 positive sentinel lymph nodes in 6 cases was detected in the obturator areas with 5 nodes $(62.5 \%)$. There were only two high graded patients in the series of 26 cases, and SLN was found in both cases. On the other hand, other patients with SLN-positivity remained as stage 1 and grade 1 (Table 2).

\section{Discussion}

In our study injecting the blue dye to the uterine fundus and SLN biopsy in the early stage endometrial cancer appeared to be a poor technique as in the data in the literature.

Sentinel lymph node biopsy and lymphatic mapping can be applied in many solid tumors. It was used as the standard procedure in cutaneous melanoma and breast cancer therapy. The technique allows evaluation of lymphatic involvement, and assists in reducing the frequency of unnecessary complete lymphadenectomy. However, although endometrial cancer is a solid tumor, due to the uncertain and complex field of lymphatic drainage, application is not ideal for lymphatic mapping. Potential regions of involvement are the obturator, internalexternal-common iliac, tibia, parametrial and presacral areas around the aortic artery. In our study, the distribution of SLN were: obturator region in $62.5 \%$, external iliac region in $25 \%$ and internal iliac region in $12.5 \%$. Due to the insufficient number of cases, the clinical relevance of SLN detection rate failed to be tested.

The injection technique and sites are also crucial. In our study, switching the technique from subserosal- fundal myometrial injection to uterine-servical combined injection reduces the detection rate. Thus, it indicates that mimicking the natural path of lymphatic drainage of the uterus has to be the priority. Considering that the technique aims to represent lymphatic drainage of the tumor, simple contradiction is inevitable; nonhysteroscopic techniques represent uterine lymphatic flow, not the tumors. To obtain accurate results, the blue dye should be injected peritumorally. Because the study was designed in a pilot manner and the hospital conditions, we did not use that protocol.

Our major handicap was the insufficient number of the patients. The criteria obtained and time interval decided was the cause of this lack. On the other hand, when data over the last decade in our clinic as the minimum specified method of surgical staging similar to this study was analysed retrospectively; in the 378 patients, only 33 (8\%) lymph node metastases were detected, and only two of them were at the early stage. In other words, only two of 313 patients $(0.06 \%)$ who were surgically staged had lymph node metastases. In this context, since the number of cases was statistically inadequate, lymph node metastases in early-stage endometrial cancer are much less frequent, so this is one of the most important issues that limits our study.

From the perspective of the learning curve, because of the low incidence of cervical and vulvar cancer, the surgeon's experience seems to be difficult to improve. However, the high incidence of endometrial cancer provides better conditions for experience. In fact, the presence of $5 \mathrm{SLN}$ of the last 9 cases in 
Table 2. Summary of all cases

\begin{tabular}{|c|c|c|c|c|c|c|c|c|c|c|c|c|c|c|c|c|c|}
\hline \multicolumn{2}{|c|}{ Case } & \multirow{2}{*}{\begin{tabular}{|c|} 
Age \\
59
\end{tabular}} & \multirow{2}{*}{$\begin{array}{c}\text { Grade } \\
1\end{array}$} & \multirow{2}{*}{\begin{tabular}{|l|} 
\\
Histology \\
Endomet. \\
\end{tabular}} & \multirow{2}{*}{$\begin{array}{c}\begin{array}{c}\text { Depth } \\
\text { of } \\
\text { invasion } \\
(>\% 50)\end{array} \\
+ \\
\end{array}$} & \multirow{2}{*}{\begin{tabular}{|c}
$\begin{array}{c}\text { Periton } \\
\text { cytology }\end{array}$ \\
-
\end{tabular}} & \multirow{2}{*}{$\begin{array}{c}\begin{array}{c}\text { Tumor } \\
\text { volume } \\
\left(\mathbf{c m}^{3}\right)\end{array} \\
60.0 \\
\end{array}$} & \multirow[t]{2}{*}{$\begin{array}{l}\text { Para- } \\
\text { aortic }\end{array}$} & \multirow{2}{*}{\begin{tabular}{|c|} 
Lymph \\
node \\
Met.
\end{tabular}} & \multirow[t]{2}{*}{ LVAI } & \multirow{2}{*}{$\begin{array}{c}\text { HT } \\
+\end{array}$} & \multirow[t]{2}{*}{ DM } & \multirow{2}{*}{\begin{tabular}{l|} 
BMI \\
31.1
\end{tabular}} & \multirow{2}{*}{\begin{tabular}{|c|} 
G* $^{*}$ \\
8
\end{tabular}} & \multirow{2}{*}{\begin{tabular}{|c|}
$\mathbf{P n}$ \\
2
\end{tabular}} & \multirow{2}{*}{\begin{tabular}{|c|} 
Menapause \\
+
\end{tabular}} & \multirow{2}{*}{$\begin{array}{c}\text { Stage } \\
2 \mathrm{~A}\end{array}$} \\
\hline $\mathrm{G}$ & $\mathrm{Z}$ & & & & & & & & & & & & & & & & \\
\hline $\mathrm{Z}$ & $\mathrm{T}$ & 56 & 2 & Endomet. & & - & 22.5 & & - & & & & 40.4 & 1 & 0 & + & $1 \mathrm{~A}$ \\
\hline A & $\mathrm{K}$ & 49 & 1 & Endomet. & & - & 17.5 & + & - & & & & 38.2 & 5 & 1 & & $2 \mathrm{~A}$ \\
\hline $\mathrm{N}$ & Ö & 57 & 1 & Endomet. & & - & 5.3 & & - & & & + & 37.5 & 4 & 3 & + & $1 \mathrm{~A}$ \\
\hline $\mathrm{F}$ & $\mathrm{Y}$ & 63 & 1 & Endomet. & & - & 0.0 & & - & & & & 30.0 & 4 & 2 & + & $1 \mathrm{~A}$ \\
\hline $\mathrm{N}$ & $\mathrm{G}$ & 58 & 2 & Endomet. & & - & 9.0 & & - & + & & & 20.5 & 0 & 0 & + & $1 \mathrm{~A}$ \\
\hline $\mathrm{N}$ & Ö & 67 & 1 & Endomet. & & - & 8.4 & & - & & + & + & 36.0 & 3 & 2 & + & $1 \mathrm{~A}$ \\
\hline $\mathbf{T}^{1}$ & $\dot{I}$ & 61 & 1 & Endomet. & + & - & 87.5 & & - & + & + & & 37.7 & 3 & 3 & + & $1 B$ \\
\hline $\mathrm{H}$ & $\mathrm{D}$ & 62 & 1 & Endomet. & + & - & 1.4 & & - & & & & 34.2 & 0 & 0 & + & 1B \\
\hline $\mathrm{G}$ & $\mathrm{U}$ & 71 & 2 & Endomet. & & - & 2.0 & & - & + & + & +1 & 38.1 & 0 & 0 & + & $1 \mathrm{~A}$ \\
\hline A & $\ddot{U}$ & 79 & 2 & Endomet. & & - & 10.0 & & - & & & & 29.1 & 6 & 3 & + & $1 \mathrm{~A}$ \\
\hline $\mathrm{F}$ & A & 46 & 2 & Endomet. & & - & 16.2 & + & - & & & & 26.1 & 3 & 2 & & $1 \mathrm{~A}$ \\
\hline $\mathrm{F}$ & $\mathrm{C}$ & 44 & 1 & Endomet. & & - & 2.6 & & - & & & & 33.8 & 2 & 2 & + & $1 \mathrm{~A}$ \\
\hline $\mathrm{R}$ & $\mathrm{U}$ & 73 & 1 & Endomet. & & - & 8.4 & & - & & + & & 28.4 & 4 & 4 & + & $1 \mathrm{~A}$ \\
\hline $\mathrm{F}$ & $\mathrm{G}$ & 66 & 1 & Endomet. & & - & 120.0 & & - & & + & & 34.3 & 2 & 2 & + & $1 \mathrm{~A}$ \\
\hline $\mathrm{A}$ & $\mathrm{K}$ & 47 & 1 & Endomet. & & - & 1.4 & & - & & + & & 32.1 & 5 & 5 & + & $1 \mathrm{~A}$ \\
\hline Ş & $\mathrm{K}$ & 54 & 1 & Endomet. & & - & 6.6 & & - & & & & 31.2 & 4 & 2 & + & $1 \mathrm{~A}$ \\
\hline $\mathbf{G}^{1}$ & $\mathbf{F}$ & 58 & 1 & Endomet. & + & - & 12.0 & & - & & + & & 40.1 & 0 & 0 & + & $1 \mathrm{~B}$ \\
\hline$Z^{1}$ & A & 60 & 1 & Endomet. & & - & 8.0 & & - & & + & & 38.7 & 5 & 3 & + & $1 \mathrm{~A}$ \\
\hline $\mathbf{M}$ & B & 58 & 3 & Serous & & - & 0.4 & & - & + & + & & 39.5 & 1 & 1 & + & $1 \mathrm{~A}$ \\
\hline $\mathrm{N}^{1}$ & $\mathrm{C}$ & 62 & 1 & Endomet. & & - & 10.5 & & - & & + & & 37.5 & 4 & 4 & & $1 \mathrm{~A}$ \\
\hline B & $\mathrm{T}$ & 47 & 1 & Endomet. & & - & 1.9 & & - & + & + & & 37.5 & 6 & 2 & & $1 \mathrm{~A}$ \\
\hline $\mathbf{S}^{1}$ & B & 60 & 1 & Endomet. & + & - & 7.5 & & - & & + & & 37.8 & 3 & 3 & + & $1 \mathrm{~B}$ \\
\hline $\mathrm{F}$ & G & 42 & 1 & Endomet. & & - & 4.5 & & - & & & & 42.1 & 6 & 4 & & $1 \mathrm{~A}$ \\
\hline $\mathbf{G}^{1}$ & $\ddot{0}$ & 52 & 3 & Clear & & - & 107.8 & & - & + & + & & 45.7 & 0 & 0 & + & $1 \mathrm{~B}$ \\
\hline A & $\mathrm{S}$ & 50 & 1 & Endomet. & & - & 2.0 & & - & & & & 39.0 & 8 & 4 & & $1 \mathrm{~A}$ \\
\hline
\end{tabular}

the study, appears to be related to the surgeon's experience. Thus, the chance to detect SLN increases with the surgeon's experience.

Another possible area of SLN technique in endometrial cancer is to determine micrometastases. Detailed histopathological examination and immunohistochemical study of endometrial cancer is indispensable for evaluating lymph nodes. In various studies, when all the lymph nodes were examined with very thin sections and IHC staining, it revealed a greater number of metastatic nodes, but it does not affect the sensitivity and negative predictive value. Therefore, the concept of sentinel lymph node biopsy provides the opportunity to establish diagnosis of micrometastases by using less effort. In our study no micrometastases were found in SLN's.
In our study, we have questioned the waiting period after injection prior to surgery and assigning the correct priority for dissection. After the subserosal and cervical injection, the mean drainage time of the dye is 30 to 60 seconds. The error rates may increase if the time interval between blue injection exceeds 20 minutes (11). According to these observations in our study, the obtained time interval seems to be appropriate, but hysterectomy before retroperitoneal lymphatic dissection appears to be the wrong option.

As a result, the basic strategy of sentinel node biopsy includes four steps: to minimize the number of patients undergoing unnecessary surgical procedure, to minimize the number of patients given unnecessary adjuvant therapy, to perform complete lymphadenectomy in patients with significant risk 
factors, and facilitating the appropriate amount of lymph node sampling by unexperienced surgeons in low risk patients. Although the SLN technique is not valuable enough to exclude lymphadenectomy, it appears to be feasible for scanning micrometastases and ultrastaging, while its clinical value has not yet been established. Although, according to the recent pilot studies, micrometastases may be adapted for the medium-risk group for local recurrence.

\section{Conflict of interest}

No conflict of interest was declared by the authors.

\section{References}

1. Silverberg E, Boring CC, Squires TS. Cancer statistics, 1990. CA Cancer J Clin 1990; 40: 9-26. [CrossRef]

2. Gusberg SB: Diagnosis and principles of treatment of cancer of the endometrium. In: Gusberg SB, Shingleton HM, Deppe G, eds. Female genital cancer. New York: Churchill 337, 1988.

3. Jemal A, Siegel R, Ward E, Murray T, Xu J, Thun MJ. Cancer statistics 2007. CA Cancer J Clin 2007; 57: 43-66. [CrossRef]

4. Lurain JR, Rice BL, Rademaker AW, Poggensee LE, Schink JC, Miller DS. Prognostic factors associated with recurrence in clini- cal stage I adenocarcinoma of the endometrium. Obstet Gynecol 1991; 78: 63-9.

5. Mariani A, Webb MJ, Keeney GL, Aletti G, Podratz KC. Predictors of lymphatic failure in endometrial cancer. Gynecol Oncol 2002; 84: 437-42. [CrossRef]

6. Mariani A, Webb M, Galli L, Podratz KC. Potential therapeutic role of paraaortic lymphadenectomy in node positive endometrial cancer. Gynecol Oncol 2000; 76: 348-56. [CrossRef]

7. Orr JW, Roland PY, Leichter D, Orr PF. Endometrial cancer: is surgical staging necessary? Curr Opin Oncol 2001; 13: 408-12. [CrossRef]

8. Holub Z, Jabor A, Kliment L. Comparison of two procedures for sentinel node detection in patients with endometrial cancer: a pilot study. Eur J Gynaecol Oncol 2002; 23: 53-7.

9. Kilgore LC, Partridge EE, Alvarez RD, Austin JM, Shingleton HM, Noojin III F, et al. Adenocarcinoma of the endometrium: survival comparison of patients with and without pelvic node sampling. Gynecol Oncol 1995; 56: 29-33. [CrossRef]

10. Cragun JM, Havrilesky LJ, Calingaert B, Synan I, Secord AA, Soper JT, et al. Retrospective analysis of selective lymphadenectomy in apparent early-stage endometrial cancer. J Clin Oncol 2005; 16 : 3668-75. [CrossRef]

11. Echt ML, Finan MA, Hoffman MS, Kline RC, Roberts WS, Fiorica JV. Detection of sentinel lymph nodes with lymphazurin in cervical, uterine, and vulvar malignancies. South Med J 1999; 92: 204-8. [CrossRef] 